\title{
BJPsych International
}

Volume 17

Number 4

November 2020

PSYCH 
BJPsych

\section{International}

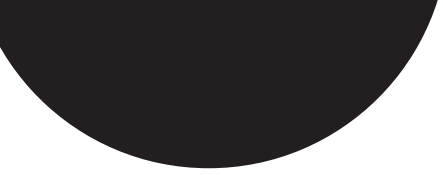

Volume 17

Number 4

November 2020

BJPsych International (Print)

ISSN 2056-4740

BJPsych International (Online)

ISSN 2058-6264
Mission of BJPsych International

We address themes that have real practical relevance to supporting patients, with a particular, but not exclusive, focus on the needs of lowand middle-income countries as well as the mental health needs of the poor and socially excluded in more developed countries. Contributors who can provide examples of innovative practice, which could be emulated elsewhere at minimal cost, are especially welcome, as are papers on public mental health.

\section{Editor}

David Skuse

\section{Founding Editor}

The late Hamid Ghodse

\section{Managing Editor}

Conceição Santos Sinclai

\section{Open access}

Online access to BJPsych International is unrestricted; use of its content is governed by the terms of the article's Creative Commons license. Please check each article for the specific Creative Commons license used.

\section{Editorial board}

\section{Deputy Editor}

Marinos Kyriakopoulos UK

\section{Senior Editorial Advisors \\ Rachel Jenkins \\ George Christodoulou (Greece)}

UK

John Cox

UK

\section{Associate Editors}

Michel Botbol (Europe)

France

Tariq Hassan (North America)

Canada

Nasser Loza (Middle East)

Egypt

Eleni Palazidou (Pandora's Box) UK
Editorial Board members

Katy Briffa (UK)

Rakesh Chadda (India)

Anna Datta (New Zealand)

Hussien Elkholy (UK)

Usman Hamdani

(Pakistan/UK)

Stephen Kisely (Australia)

Gholam Reza Mir-Sepassi

(Iran)

Hellme Najim (UK)

David Ndetei (Kenya)

Patrick Nwagbogu (UK)

Sundararajan Rajagopal

(India)

Mohamed Omar Salem

(UAE)
Digital Content Editors

Golnar Aref-Adib (UK)

Alison Blatcher (UK)

Mallika Punukollu (UK)

Sachin Shah (UK)

Pictures Editor

Georgina Corbet-Burcher

(UK)

\section{Trainee Editors}

Dami Ajayi (UK)

Khalid Elzamzamy (Qatar)

\section{Access}

BJPsych International is Open Access online. Print copies are provided to members of the Royal College of Psychiatrists free of charge.

\section{About the journal}

BJPsych International is published four times a year on behalf of the Royal College of Psychiatrists, which is a charity registered in England and Wales (228636) and in Scotland (SC038369).

BJPsych International is hosted on the Cambridge Core service at https://www.cambridge.org/core/journals/ bjpsych-international

Information about the College's publications is available at https://www.rcpsych.ac.uk

The views presented in this publication do not necessarily reflect those of the Royal College of Psychiatrists, and the publishers are not responsible for any error of omission or fact.

Formerly published as International Psychiatry (20032014), ISSN 1749-3676, and until 2006 was subtitled as the Bulletin of the Board of International Affairs of the Royal College of Psychiatrists.

Printed in Great Britain by Henry Ling Limited, The Dorset Press, Dorchester, Dorset DT1 1HD.

This journal issue has been printed on $\mathrm{FSC}^{\mathrm{m}}$-certified paper and cover board. FSC is an independent, non-governmental, not-for-profit organization established to promote the responsible management of the world's forests. Please see www.fsc.org for information.

Design (C) The Royal College of Psychiatrists 2020 .

\section{Notice to contributors}

BJPsych International publishes articles dealing with mental health policy, promotion and legislation, the administration and management of mental health services, and training in psychiatry around the world. The journal aims to be a platform for work that is generally underrepresented in the literature, especially psychiatry in low-and middle-income countries.

Manuscripts for publication should be submitted online at https://mc.manuscriptcentral.com/bjpsych-int (general enquiries may be addressed to ip@rcpsych.ac.uk).

Manuscripts accepted for publication are copy-edited to improve readability and to ensure conformity with house style. Authors whose first language is not English are encouraged to contribute.

Contributions are accepted for publication on the condition that their substance has not been published or submitted elsewhere. Once a paper is accepted for publication, all its authors are required to disclose any potential conflict of interest. Completion of the form developed by the International Committee of Medica Journal Editors for this purpose (http://www.icmje.org/ conflicts-of-interest/) is mandatory.

\section{About our peer review process}

All articles submitted are reviewed by a minimum of two peers to ensure that their content, length and structure are appropriate for the journal. Not all papers will be accepted for publication, but our peer review process is intended to assist our authors in producing articles for worldwide dissemination. Wherever possible, our expert panel of assessors will help authors to improve their papers to maximise their impact when published.

\section{USPS ID Statement}

B]Psych International, ISSN 2056-4740, is published four times a year by Cambridge University Press, UPH, Shaftesbury Road, Cambridge CB2 8BS, UK. There are no paid subscriptions to the journal. Airfreight and mailing in the USA by agent named World Container Inc, 150-15, 183rd Street, Jamaica, NY 11413, USA. Periodicals postage paid at Brooklyn, NY 11256. US Postmaster: Send address changes to BJPsych International, World Container Inc, 150-15, 183rd Street, Jamaica, NY 11413 USA Subscription records are maintained at Cambridge University Press, UPH, Shaftesbury Road, Cambridge CB2 8BS, UK. Air Business Ltd is acting as our mailing agent.

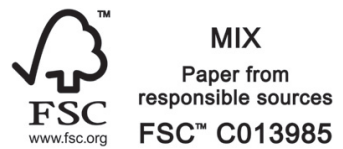

